\title{
Age of the Jurassic hemipelagic sediments from the Ljubiš area (Zlatibor Mt., SW Serbia)
}

\author{
Nikita Bragin ${ }^{1 *}$ and Nevenka Djerić ${ }^{2}$ \\ ${ }^{1}$ Geological Institute RAS, Pyzhevsky 7, 119017 Moscow, Russia; (*corresponding author: bragin.n@mail.ru) \\ 2 University of Belgrade, Faculty of Mining and Geology, Kamenička 6, 11000 Belgrade, Serbia; (nevenka.djeric@rgf.bg.ac.rs)
}

doi: $10.4154 / g c .2020 .11$

Article history:

Manuscript received January 24, 2020

Revised manuscript accepted July 29, 2020

Available online October 22, 2020
Keywords: Radiolaria, Dinarides, Jurassic stratigraphy, Serbia

\begin{abstract}
The type section of the Ljubiš Formation, (Djokov Potok, Zlatibor area, western Serbia) is characterized by abundant poorly-to-moderately preserved radiolarians. The lower part of the type section is characterized by Middle Jurassic (?Bajocian to Bathonian) radiolarian assemblages with Japonocapsa fusiformis (YAO), Takemuraella weghae (GRILL \& KOZUR), Eoxitus hungaricus KOZUR, E. baloghi KOZUR, Helvetocapsa matsuokai (SASHIDA), Quarkus japonicus (YAO), Hexasaturnalis suboblongus (YAO), $H$. tetraspinus (YAO). Taking into account previous data from the upper part of the Ljubiš Formation, the age of the formation can be estimated to be in the interval from the ?Bajocian to Bathonian-Oxfordian. The new biostratigraphic data clearly show the onset of tectonic motion in the Middle Jurassic, documented by the presence of mass transport deposits intercalated in the radiolarite successions. This suggests a Middle Jurassic onset of ophiolite obduction which triggered the rapid deepening of the Adria margin, documented by the abrupt change from carbonate to radiolarite deposition.
\end{abstract}

\section{INTRODUCTION}

Various Mesozoic radiolarite deposits are common and widespread in the territory of western and southwestern Serbia. Mesozoic radiolaria are found in pelagic and hemipelagic sediments deposited on the Neo-Tethys ocean floor, intercalated between Triassic shallow-water carbonate ramp and platform sediments, and are widespread in Jurassic times on the Adriatic margin. Their age determination, stratigraphy, and facies are important for the reconstruction of tectonic motion and the arrangement of palaeo-oceanic basins and continental blocks. Due to the highly complicated structure of this territory, each palaeontological datum from radiolarite deposits and from carbonate clasts of the intercalated turbidites is highly important.

Radiolarians are the most often utilized fossils in such biostratigraphic studies, due to their common presence in the Mesozoic radiolarites. Mesozoic radiolarian biochronology is essential for the understanding of the palaeogeography and overall tectonic structure of the Dinarides. There are numerous data on siliceous sedimentary rocks associated with the ophiolite belts in the Dinarides, Albanides and Hellenides which are often Middle to Late Triassic, Middle Jurassic, or late Middle Jurassic to Late Jurassic in age (OBRADOVIĆ \& GORIČAN, 1988; DJERIĆ et al., 2007; CHIARI et al., 2011; FERRIÈRE et al., 2015; GAWLICK et al., 2017; BRAGIN et al., 2019b). It is very rarely possible to obtain Early Jurassic ages, and radiolarites of Early Jurassic age were only discovered in two sections, at Angelokastron and Vothiki (Argolis), (CHIARI et al., 2013).

Numerous radiolarian studies have been carried out in Serbia during the last two decades (e.g. GORIČAN et al., 1999; DJERIĆ et al., 2007, 2012; GAWLICK et al., 2009, 2016, 2018; VISHNEVSKAYA et al., 2009; CHIARI et al., 2011; BRAGIN et al., 2011, 2019a, b) but a lot of the biostratigraphic age dating has still to be undertaken to solve the remaining open questions. The difficult reconstruction of the geodynamic history of the Adriatic passive margin and the ophiolite belts in the Dinarides needs careful analysis of all sedimentary deposits, including their biostratigraphy, facies, history of deposition, and tectonic events.

In recent work GAWLICK et al. (2017), SUDAR \& GAWLICK (2018) and GAWLICK \& MISSONI (2019) propose a new stratigraphic scheme for the Triassic and Jurassic of the Inner Dinarides. Numerous stratigraphic series (formations) were analyzed: some of them were revised, others were established for the first time. Radiolarite formations in this scheme are most common in the Middle and Upper Jurassic deposits. Biostratigraphic data of these numerous formations are variable. In some instances they are very comprehensive, while in the other cases they are scarce or rare. Some formations still have only limited biostratigraphic control and their stratigraphic positions were determined by indirect methods. GAWLICK et al. (2017) recently proposed a late Middle Jurassic to Late Jurassic age for the Ljubiš Formation, but the dating was not precise due to poor preservation of the radiolarians.

During the 2015 field season, we studied the reference section of the Ljubiš Formation (sensu GAWLICK et al., 2017) in Djokov Potok, and present here the first biostratigraphic data from these sedimentary rocks based on radiolarians.

\section{GEOLOGICAL OVERVIEW}

The research area is situated in SW Serbia, in Ljubiš Village on the eastern flanks of Mt. Zlatibor. The wider area is characterized by a rather complicated structure. According to SCHMID et al. (2008), it comprises the Adria-derived Drina-Ivanjica (DIU) and East Bosnian-Durmitor Units (EBDU), with the West Vardar ophiolites superimposed on top, i.e. presently located between the DIU to the northeast and the EDBU to the southwest (Fig.1). Both Adria-derived units (Drina-Ivanjica and East Bosnian-Durmitor) being thrust by the ophiolitic mélange during the Late Jurassic (SCHMID et al., 2008). The present-day position of the Drina-Ivanjica above the East Bosnian-Durmitor unit is a result of out-of-sequence thrusting during the Cretaceous (SCHMID et 


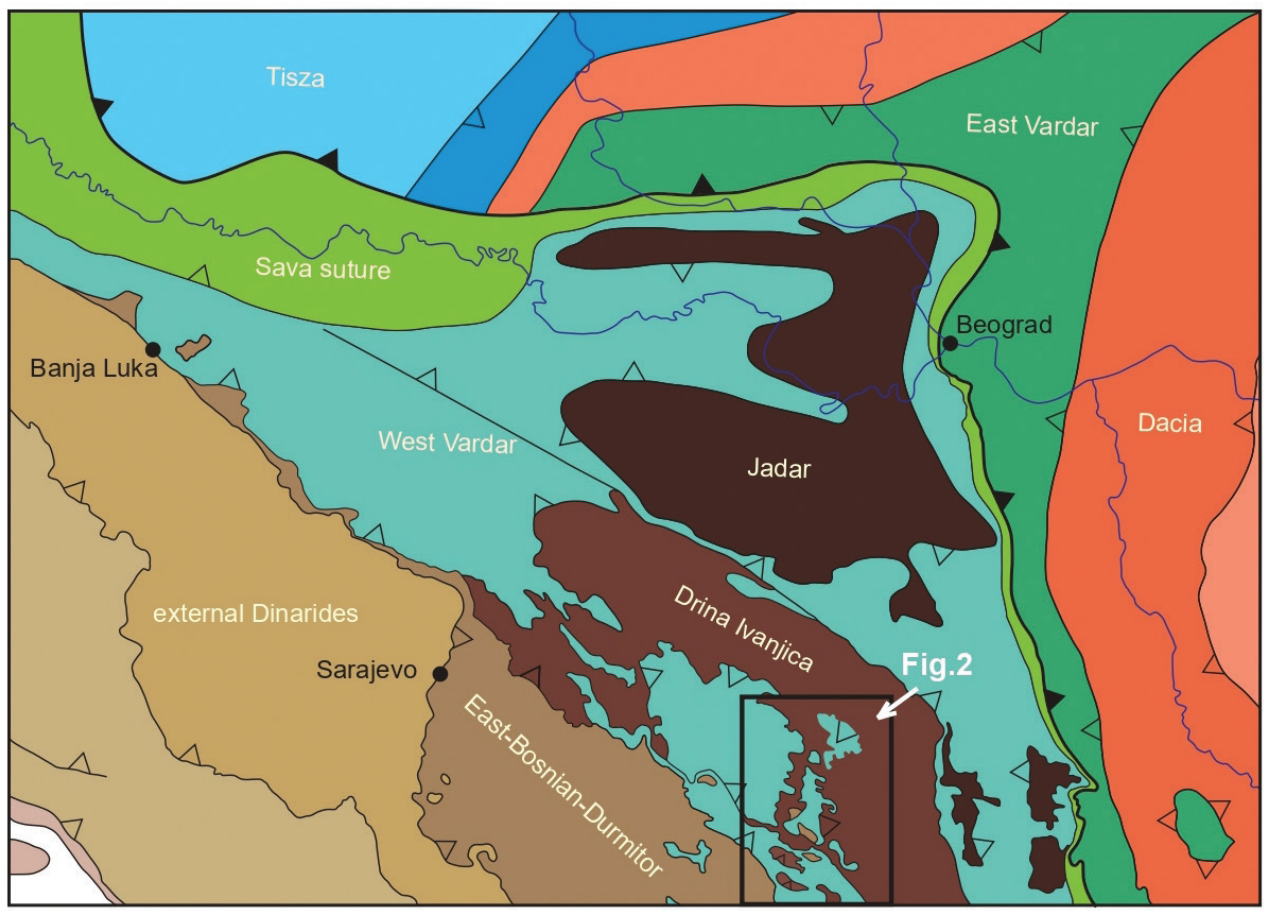

Figure 1. The main tectonic units of Serbia and adjacent territories (modified after SCHMID et al., 2008).

\section{Drina-Ivanjica Unit}

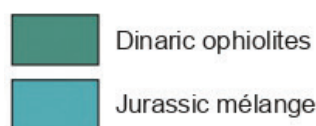

—. Latest Jurassic obduction

::::: Sediments of the Adriatic passive margin (Jurassic, mostly radiolarites)

Sediments of the Adriatic passive margin (Paleozoic and Triassic)

\section{Pre-Senonian thrust}

\section{East-Bosnian-Durmitor Unit}

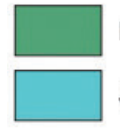

Dinaric ophiolites

Jurassic mélange

Latest Jurassic obduction

Sediments of the Adriatic passive margin (Jurassic, mostly radiolarites)

Sediments of the Adriatic passive margin (Paleozoic and Triassic)

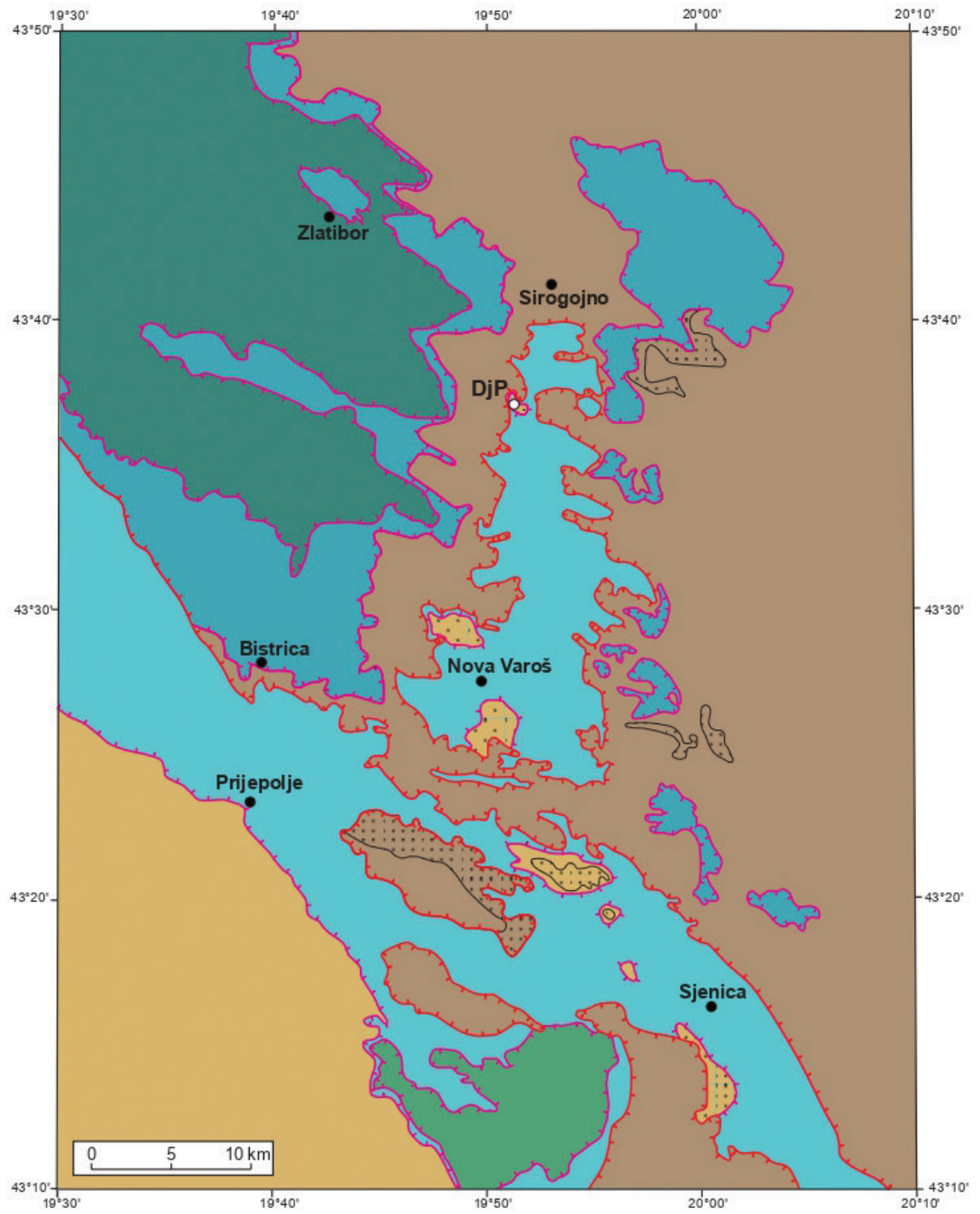

Figure 2. A simplified geologic map of the Zlatibor-Zlatar area with the position of the Djokov Potok section (modified after DJERIĆ et al., 2012). 
al., 2008) or Late Jurassic (Tithonian; GAWLICK \& MISSONI, 2019). GAWLICK et al. (2017) note that in Triassic-Jurassic times these two units (Drina-Ivanjica and East-Bosnian Durmitor) were part of the same shelf - the Drina-Ivanjica Unit (slightly metamorphosed) represents a more distal shelf area than the East Bosnian-Durmitor Unit (unmetamorphosed).

According to DJERIĆ et al. (2007), radiolarites of the Djokov Potok section, as a part of the Triassic-Jurassic sedimentary succession formed along the Adriatic passive margin, belong to the East Bosnian-Durmitor Unit (Fig. 2).

The East Bosnian-Durmitor Unit was defined by DIMITRIJEVIĆ (1974) and corresponds to the "Zone Serbe" of RAMPNOUX (1970) and AUBOUIN et al. (1970). According to SCHMID et al. (2008) the East Bosnian Durmitor Unit comprises two sub-units, the more external Durmitor sub-unit (Montenegro) and the more internal Lim sub-unit (SW Serbia). The Triassic of the Durmitor sub-unit is characterized by thick carbonate platform sediments (RAMPNOUX, 1970; PANTIĆ \& RAMPNOUX, 1972), while the more internal Lim sub-unit is characterized by a more distal slope or basinal facies represented by cherty limestones (the "Grivska Formation", DIMITRIJEVIĆ \& DIMITRIJEVIĆ, 1991) and a Late Triassic reefal and slope facies (DIMITRIJEVIĆ, 1997). Recently, all Grivska Formation occurrences are attributed to the allochthonous and far-travelled nappe with a palaeogeographic derivation far to the east (GAWLICK et al., 2017). At the beginning of the Jurassic, the carbonate platforms in the Inner Dinarides were drowned and a relatively sudden deepening of the Adriatic shelf in the Middle Jurassic resulted in widespread deposition of radiolarites (DJERIĆ et al., 2012; VISHNEVSKAYA et al., 2009). All these sediments were overthrust by the ophiolitic mélange and overlying ophiolites in the Late Jurassic (Fig. 2).

\begin{tabular}{|c|c|c|c|c|}
\hline & & $\begin{array}{l}\text { East Bosnian- } \\
\text { Durmitor } \\
\text { Unit }\end{array}$ & $\begin{array}{l}\text { Dinaridic } \\
\text { Ophiolite } \\
\text { Belt }\end{array}$ & $\begin{array}{l}\text { Drina- } \\
\text { Ivanjica } \\
\text { Unit }\end{array}$ \\
\hline \multirow{3}{*}{ 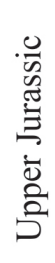 } & Tithonian & \\
\hline & Kimmeridgian & \multicolumn{3}{|c|}{ unnamed Formation } \\
\hline & Oxfordian & \multicolumn{3}{|c|}{ Radiolarite Group } \\
\hline \multirow{4}{*}{ 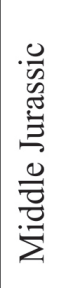 } & Callovian & \multicolumn{2}{|c|}{ Gonje Formation } & $\begin{array}{l}\text { Radiolarite } \\
\text { Group }\end{array}$ \\
\hline & Bathonian & \multirow{2}{*}{\multicolumn{2}{|c|}{ 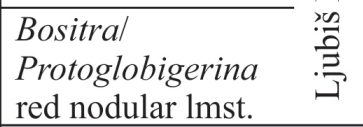 }} & \\
\hline & Bajocian & & & Eroded \\
\hline & Aalenian & \multicolumn{2}{|c|}{ stratigraphic gap } & $?$ \\
\hline \multirow{4}{*}{ 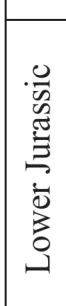 } & Toarcian & \multirow{2}{*}{\multicolumn{2}{|c|}{ 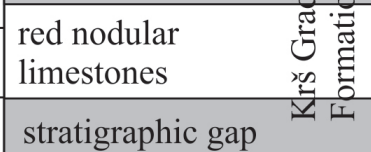 }} & $\begin{array}{l}\text { red nodular } \\
\text { limestones }\end{array}$ \\
\hline & Pliensbachian & & & $?$ \\
\hline & Sinemurian & \multicolumn{3}{|c|}{ grey limestones } \\
\hline & Hettangian & \multicolumn{2}{|c|}{ stratigraphic gap } & $?$ \\
\hline $\operatorname{Tr}$ & Rhaetian & \multicolumn{3}{|c|}{ Dachstein Carbonate Platform } \\
\hline
\end{tabular}

Figure 3. The main Jurassic lithostratigraphic units of the Inner Dinarides (GAWLICK et al., 2017).
In contrast to these interpretations GAWLICK et al. (2017) excluded the Late Triassic reefal and slope facies as remnants of an overthrust nappe. During the last few years investigations carried on in SW Serbia (GAWLICK et al., 2017 and references therein) have been focused on the litho- and microfacies analysis, and biostratigraphic analysis of the components of the mélanges. Based on the data obtained, GAWLICK et al. (2017, p. 4) concluded: "The ophiolite and distal continental margin nappes including different mélanges rest today as polyphase far travelled transported nappe stack on an parautochthonous Triassic-Jurassic sedimentary sequence that was palaeogeographically situated between the East Bosnian Durmitor Unit and Drina-Ivanjica Unit".

In the Inner Dinarides, besides the sub-ophiolitic mélange, these authors also distinguish different parautochthonous sequences below the overthrust units. According to GAWLICK \& MISSONI (2019 and references therein) sedimentary mélanges derived from sedimentation processes in deep-water trench-like foreland basins in front of the propagating nappes triggered by ophiolite obduction. These deep-water basins were supplied by the erosional products of the advancing nappe stack and embedded in a radiolarite bearing argillaceous matrix. According to these authors, the Djokov Potok locality in the Ljubiš village is the type section of the newly established Ljubiš Formation (Fig. 3). These Jurassic radiolarites intercalated with calciturbidites deposited in a trench-like basin (Ljubiš Basin) outcrop in a tectonic window below the overthrust allochthonous units (ophiolitic mélange and Sirogojno Mélange), and belong to the parautochthonous sequences between the Drina-Ivanjica Unit to the east and the East Bosnian Durmitor Unit to the west (GAWLICK et al., 2017).

\section{SECTION DESCRIPTION AND BIOSTRATIGRAPHY}

The studied section is located in Donji Ljubiš Village and starts from the lower flow of Djokov Potok creek to the west and uphill. The coordinates of the starting point of the section are $\mathrm{N} 43^{\circ} 37^{\prime}$ $14.0^{\prime \prime} \mathrm{E} 19^{\circ} 50^{\prime} 56.1^{\prime \prime}$. We studied and sampled the lower part of this section up to the point N $43^{\circ} 37^{\prime} 16.0^{\prime \prime} \mathrm{E} 19^{\circ} 50^{\prime} 54.5^{\prime}$ '. The underlying formation is not visible at the surface. A geological column of the section is shown in Fig. 4. The section begins with a two-metre thick unit consisting of calcareous mass transport deposits and turbidites intercalated with dark-grey radiolarites (GAWLICK et al., 2017) (Unit 1). Five metres of dark greenishgrey thin-bedded radiolarites intercalated with greenish-grey cherty claystone follow (Unit 2) (Fig. 5A, B). The next unit in the column is a $0.5 \mathrm{~m}$ thick grey massive calcarenite (Unit 3 ). Further up in the column, there are dark greenish-grey thin-bedded radiolarites intercalated with greenish-grey cherty mudstone. Thin calcarenite beds appear $3 \mathrm{~m}$ above the base of this unit. The whole unit (Unit 4 ) is $8 \mathrm{~m}$ thick. Unit 5 comprises $1 \mathrm{~m}$ of a grey massive calcarenite (Fig. 5C). The section ends with $12 \mathrm{~m}$ of dark greenish-grey thin-bedded radiolarites intercalated with greenish-grey cherty mudstones (Unit 6) (Fig. 5D).

Radiolarites of this formation are characterized by an abundance of radiolarian tests, but they are generally strongly recrystallized and very poorly preserved. Sometimes the radiolarians cannot be extracted from the rock: they become partly or completely dissolved during the maceration process. Radiolarites were sampled and processed by the traditional method. Small $(100 \mathrm{~g})$ pieces of rocks were etched by diluted (5-10\%) hydrofluoric acid (HF) for 12 hours. Then the residue was washed with water and dried. 
Table 1. Species occurrence list of radiolarians from the Middle Jurassic Djokov Potok section.

\begin{tabular}{|c|c|c|c|c|}
\hline Radiolarian taxa & $15-10-7$ & $15-10-8$ & $15-10-10$ & $15-10-11$ \\
\hline Japonocapsa fusiformis (YAO) & $\mathrm{R}$ & & & $\mathrm{R}$ \\
\hline Eoxitus hungaricus KOZUR & c & & & \\
\hline Parahsuum sp. & $\mathrm{R}$ & & & \\
\hline Quarkus japonicus (YAO) & C & & & \\
\hline Helvetocapsa matsuokai (SASHIDA) & C & & & \\
\hline $\begin{array}{l}\text { Eucyrtidiellum sp. cf. E. unumaense s.l. } \\
\text { (YAO) }\end{array}$ & $\mathrm{R}$ & & & \\
\hline Quarticella sp. & c & & & \\
\hline Parvimitrella sp. & $\mathrm{R}$ & & & \\
\hline $\begin{array}{l}\text { Campanomitra? sp. A sensu O'Dogherty, } \\
\text { Goričan \& Gawlick, } 2017\end{array}$ & $\mathrm{R}$ & & & \\
\hline Praewilliriedellum sp. & C & C & & \\
\hline $\begin{array}{l}\text { Hsuum sp. cf. H. matsuokai ISOZAKI \& } \\
\text { MATSUDA }\end{array}$ & & $\mathrm{R}$ & & \\
\hline Praewilliriedellum convexum (YAO) & & & C & \\
\hline $\begin{array}{l}\text { Parahsuum sp. cf. P. izeense (PESSAGNO \& } \\
\text { WHALEN) }\end{array}$ & & & C & \\
\hline Parahsuum sp. & & & $\mathrm{R}$ & \\
\hline Takemuraella veghae (GRILL \& KOZUR) & & & $\mathrm{R}$ & $\mathrm{R}$ \\
\hline Hsuum sp. cf. H. baloghi GRILL \& KOZUR & & & C & \\
\hline $\begin{array}{l}\text { Quarticella sp. D sensu O'DOGHERTY, } \\
\text { GORIČAN \& GAWLICK, } 2017\end{array}$ & & & $\mathrm{R}$ & \\
\hline Hexasaturnalis suboblongus (YAO) & & & $\mathrm{R}$ & \\
\hline Hexasaturnalis tetraspinus (YAO) & & & $\mathrm{R}$ & \\
\hline Transhsuum sp. & $\mathrm{R}$ & & $\mathrm{R}$ & C \\
\hline Eoxitus baloghi KOZUR & & & & C \\
\hline $\begin{array}{l}\text { Parahsuum sp. cf. P. indomitum } \\
\text { (PESSAGNO \& WHALEN) }\end{array}$ & & & & $\mathrm{R}$ \\
\hline Mizukidella sp. & & & & $\mathrm{R}$ \\
\hline Hsuum sp. & & & & $\mathrm{R}$ \\
\hline Theocapsomella sp. & & & & $\mathrm{R}$ \\
\hline
\end{tabular}

Unit 4 is characterized by poorly preserved specimens. Some of them can be identified to generic level or in open nomenclature (Table 1, Fig. 6, Plate 1, Figs. A-C, E-K). The fourth unit, consisting of dark greenish-grey, thin-bedded radiolarite, contains the next datable samples:

Sample 15-10-7 contains the following radiolarian assemblage: Japonocapsa fusiformis (YAO) (= Tricolocapsa fusiformis, in BAUMGARTNER et al., 1995a), Eoxitus hungaricus Kozur, Helvetocapsa matsuokai (SASHIDA), Quarkus japonicus (YAO) (= Stichocapsa japonica, in BAUMGARTNER et al., 1995a), Eucyrtidiellum sp. cf. E. unumaense s.l. (YAO), Quarticella sp., Hsuum sp., Parahsuum sp., Parvimitrella sp. (Plate 1, Table 1). On the basis of the presence of Japonocapsa fusiformis (YAO), an early-middle Bajocian to late Bajocian-early Bathonian (UAZs 3-5; BAUMGARTNER et al., 1995b) age can be inferred. However, SUZUKI \& GAWLICK (2009) found this species also in association with younger radiolarians in several samples indicating that this species may also be present in younger deposits Callovian and even in the lower Oxfordian (GAWLICK, pers. comm.). Other taxa have broad stratigraphic ranges: Helvetocapsa matsuokai was found in the middle-late Callovian (SUZUKI \& GAWLICK, 2009), and Quarticella sp. is present in the Callovian (GAWLICK et al., 2009). Therefore, we have to estimate a wide stratigraphic range for this sample - Bajocian to Callovian.
Sample $15-10-8$ is characterized by a poor and badly preserved radiolarian assemblage. The age could not be determined because it contains only Campanomitra? sp. A sensu O'DOGHERTY, GORIČAN \& GAWLICK, 2017 and Praewilliriedellum sp.

Radiolarites from Unit 6 are characterized by better preservation of the radiolarians (Table 1, Fig. 6, Plate 1, Figs. D, L-P, Plate 2). Samples 15-10-10 and 15-10-11 were taken from the sixth unit (made up of dark greenish-grey thin-bedded radiolarites, with interlayers of greenish-grey cherty mudstones).

Sample 15-10-10 yields several radiolarian species with concurrent stratigraphic ranges that allow us to date them. The most important feature of sample 15-10-10 is the co-occurrence of Hexasaturnalis suboblongus (YAO) (= Acanthocircus suboblongus, in BAUMGARTNER et al., 1995a) and H. tetraspinus (YAO) which suggests the interval from UAZ 3 to UAZ 6 (early-middle Bajocian to middle Bathonian) (BAUMGARTNER et al., 1995b). Additionally, the presence of Takemuraella weghae (GRILL \& KOZUR) and Hsuum sp. cf. H. baloghi GRILL \& KOZUR confirms the Bajocian-Bathonian age determination (GRILL \& KOZUR, 1986; O’DOGHERTY et al., 2006; 2017).

Considering the stratigraphic position of sample 15-10-10 within the entire section (see Fig. 4) and the age of sample 15-10-11

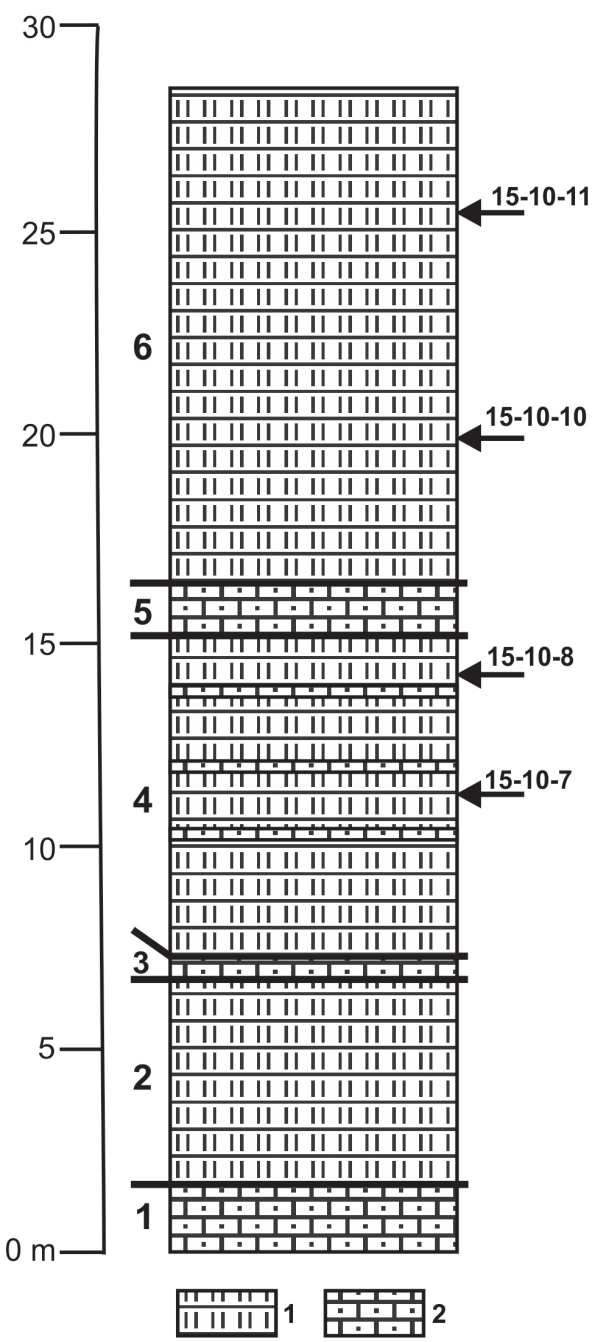

Figure 4. A lithological column of the lower part of the Djokov Potok section (Ljubiš Formation). The numbers of units are shown to the left of the column. Positions of samples with radiolarians are indicated on the right of the column by arrows. 1 - radiolarites and mudstones; 2 - limestones and calcarenites. 


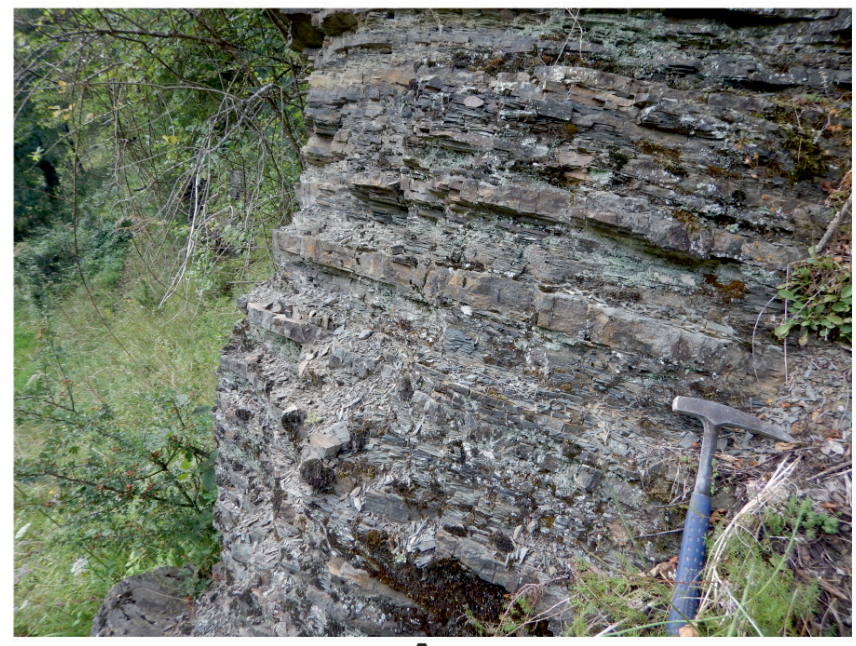

A

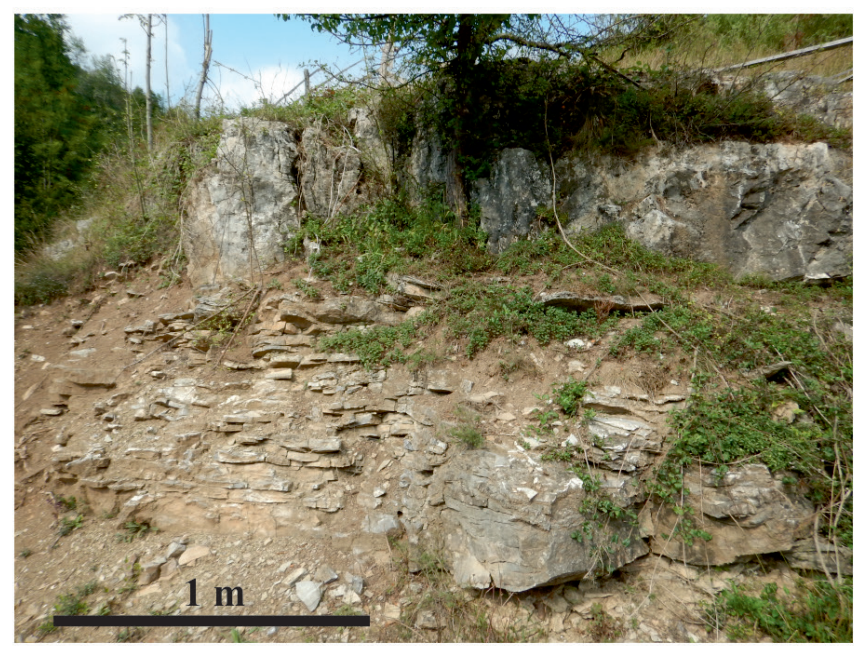

C

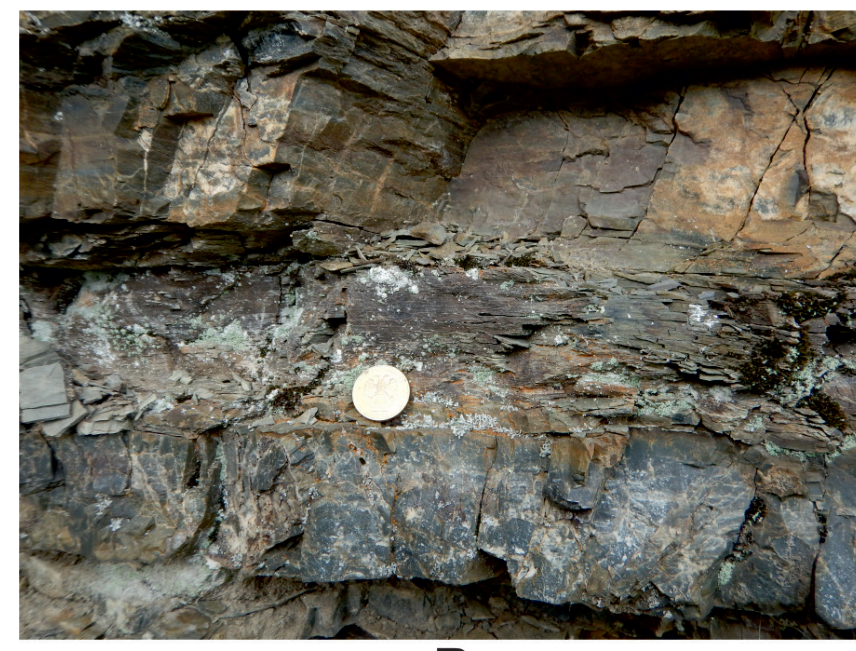

B

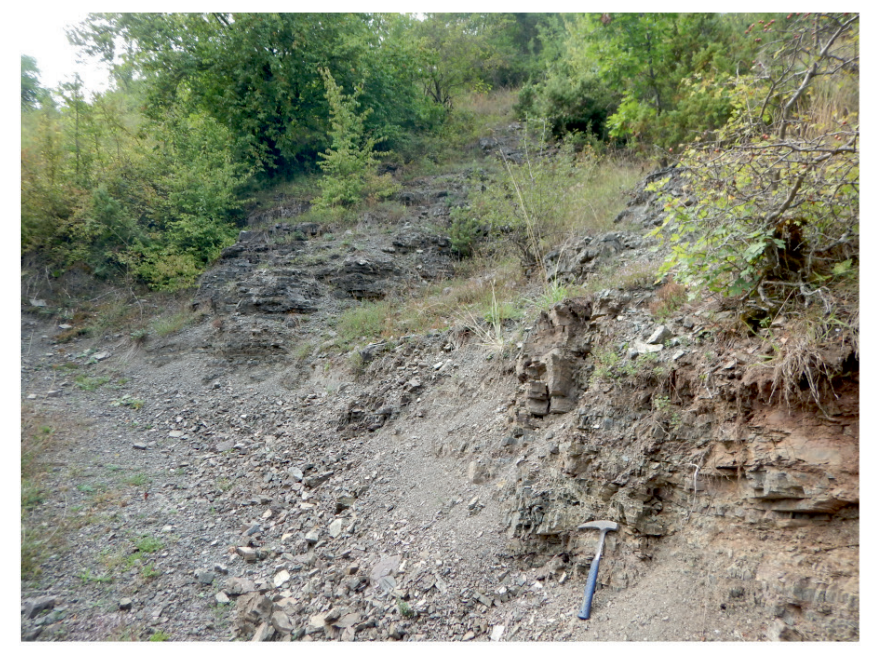

D

Figure 5. Outcrops of the Ljubiš Formation in Djokov Potok. A - grey bedded radiolarites intercalated with grey cherty mudstones, unit 2; B - detail of radiolaritemudstone intercalation, unit 2; C - grey massive calcarenite, unit 5, below are radiolarites of unit 4; D - bedded radiolarites of unit 6 .

discussed below, the age of this sample ranges from the Bajocian to the Bathonian (UAZs 3-6). The Bathonian age seems to be more likely due to previous studies (GAWLICK et al., 2017).

Sample 15-10-11 was taken from the uppermost layers of this unit. The following species were identified from the radiolarian association: Takemuraella weghae (GRILL \& KOZUR), Eoxitus baloghi KOZUR, Japonocapsa fusiformis (YAO), Pseudoristola sp. cf. P. durisaeptum (AITA) (=Amphipyndax durisaeptum, in BAUMGARTNER et al., 1995a), Parahsuum sp. cf. P. indomitum (PESSAGNO \& WHALEN), Mizukidella sp., Hsuum sp., Transhsuum sp., Theocapsomella sp. Due to the presence of Takemuraella weghae the assemblage is compatible with UAZs 3 to 6, covering the time span from the Bajocian to the Bathonian.

As some taxa were determined in open nomenclature and their data adequacy is relatively low, we can conclude that the lower part of the Ljubiš Formation has a Middle Jurassic, ?Bajocian to Bathonian age.

\section{DISCUSSION}

The Ljubiš Formation was proposed by GAWLICK et al. (2017) as a possible age equivalent of the Middle to Upper Jurassic (Bathonian-Tithonian) Gonje Formation (VISHNEVSKAYA et al., 2009) developed in the western part of the Dinaridic Ophiolite belt (Fig. 3). The Gonje Formation is represented by various co- loured radiolarites with intercalated mass transport deposits and turbidites in the upper part and dated by radiolarians and foraminifers (RADOIĆIĆ et al., 2009). According to GAWLICK et al. (2017) the mass transport deposits in the upper part of the Gonje Formation (Kimmeridgian-Tithonian age) have a completely different component spectrum to that of the Ljubiš Formation. In contrast to the Gonje Formation the Ljubis Fm. contains Late Triassic lagoonal and back-reefal Dachstein Limestone and some condensed Early and Middle Jurassic components from the overlying of the Dachstein Limestone in the lower part, and in the upper part additional Late Jurassic shallow-water components; the Gonje Fm. contains various clasts, e.g. Late Jurassic shallow-water clasts; open-marine Late Triassic limestone clasts, various heavy minerals and others (GAWLICK et al., 2017). The Ljubiš Formation was dated at the type-locality only by the presence of the radiolarian specimen Eucyrtidiellum sp. cf. E. unumaense (GAWLICK et al., 2017). Also, bedded greenish-grey radiolarites with intercalated turbidites of the Ljubiš Formation are preserved below the overthrust ophiolitic mélange in the double road curve south of Ljubiš (between Ljubiš and Jasenovo). These radiolarites from the ophiolitic mélange, GAWLICK et al. (2016), were dated by a better preserved radiolarian assemblage (Callovian to Middle Oxfordian age). GAWLICK et al. (2017) reported a latest Bajocian to middle Oxfordian age from the Ljubiš 


\begin{tabular}{|c|c|c|c|c|c|c|c|c|c|}
\hline \multirow{2}{*}{ 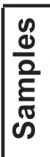 } & Stages & \multicolumn{2}{|c|}{ Aalenian } & \multicolumn{2}{|c|}{ Bajocian } & \multicolumn{2}{|c|}{ Bathonian } & \multicolumn{2}{|c|}{ Callovian } \\
\hline & $\begin{array}{lr}\text { Radiolarian taxa } & \begin{array}{c}\text { Zones (BAUMGARTNER } \\
\text { et al., 1995b) }\end{array} \\
\end{array}$ & 1 & 2 & 3 & 4 & 5 & 6 & 7 & 8 \\
\hline 홍 & $\begin{array}{l}\text { Japonocapsa fusiformis (YAO) } \\
\text { Eoxitus hungaricus KOZUR } \\
\text { Quarkus japonicus (YAO) } \\
\text { Helvetocapsa matsuokai (SASHIDA) }\end{array}$ & & & & & & & & \\
\hline$\stackrel{n}{2}$ & $\begin{array}{l}\text { Eucyrtidiellum sp. cf. E. unumaense s.I. (YAO) } \\
\text { Quarticella sp. }\end{array}$ & & & & & & & & \\
\hline 웋 & $\begin{array}{l}\text { Praewilliriedellum convexum (YAO) } \\
\text { Takemuraella weghae (GRILL \& KOZUR) } \\
\text { Hsuum sp. cf. H. baloghi GRILL \& KOZUR } \\
\text { Quarticella sp. D. sensu O'DOGHERTY, GORIČAN \& }\end{array}$ & & & & & & & & \\
\hline & $\begin{array}{l}\text { Hexasaturnalis suboblongus (YAO) } \\
\text { Hexasaturnalis tetraspinus (YAO) }\end{array}$ & & & & & & & & \\
\hline$\frac{\check{c}}{\grave{c}}$ & $\begin{array}{l}\text { Eoxitus baloghi KOZUR } \\
\text { Parahsuum sp. cf. P. indomitum (PESSAGNO \& WHALEN) } \\
\text { Takemuraella weghae (GRILL \& KOZUR) } \\
\text { Pseudoristola sp. cf. P. durisaeptum (AITA) } \\
\text { Japonocapsa fusiformis (YAO) }\end{array}$ & & & & & & & & \\
\hline
\end{tabular}

Figure 6. The stratigraphic ranges of selected radiolarian taxa and the stratigraphic position of the studied samples. Dotted lines show the stratigraphic ranges of taxa determined in open nomenclature and taxa for which the stratigraphic range needs more detailed study. Stratigraphic ranges were attributed according to BAUMGARTNER et al. (1995b) with additional data from SUZUKI \& GAWLICK (2009) and GAWLICK et al. (2009).

Formation on the western slope of Vis Mountain. According to GAWLICK et al. (2017) the preserved part of the Ljubiš basin represents a more proximal part of the basin and the thickness of this basin fill is at least $400 \mathrm{~m}$. In the currently uninvestigated most proximal parts of this basin the authors expected a much thicker sequence (up to $1000 \mathrm{~m}$ ). It should be mentioned that in the type area, the underlying Bositra limestones do not outcrop. Also, it is important to note that turbiditic layers, common in the Ljubiš Formation, yield Upper Triassic to Middle Jurassic components (GAWLICK et al., 2017): the Triassic components were derived from the lagoonal Dachstein carbonate platform, while the Lower and Middle Jurassic clasts are represented by red nodular limestone and Bositra-limestone. GAWLICK et al. (2017) supposed that this turbidite material was derived from the Upper Triassic-Middle Jurassic sedimentary succession of the DIU, however, the Krš Gradac quarry contains only Late Triassic clasts from the fore-reef.

On the basis of our new data the analyzed radiolarites (the lower part of Ljubiš Formation) were deposited in the time period of the Bajocian to the Bathonian. The Ljubiš Formation above our samples contains reworked Middle Jurassic Bositra limestone clasts (GAWLICK et al., 2017), known mainly from the BajocianBathonian, so these radiolarites should be younger than the reworked clasts. Anyway, the deposition of the Ljubiš Formation could have started earlier than previously thought - in the early Bathonian or even in the late Bajocian. Further study of the biostratigraphy and detailed analysis of the sections would be needed to achieve a better understanding of the composition and nature of the Ljubiš Formation.

\section{CONCLUSIONS}

Middle Jurassic (Bajocian-Bathonian) radiolarian assemblages were discovered in radiolarites of the lower part of the Ljubiš Formation in the type section in Djokov Potok (Ljubiš village, SW Serbia). The age of the samples cannot be assigned very precisely due to the poor preservation of the radiolarians. The whole stratigraphic range of the Ljubiš Formation could range from the lower-middle Bajocian to the Oxfordian if we take into account previous Bathonian-Oxfordian radiolarian data from the upper part of the formation (GAWLICK et al., 2017). The newly deter- mined biostratigraphic ages based on radiolarian faunas clearly show the onset of tectonic motion in the Middle Jurassic, documented by the deposition of mass transport deposits intercalated in thick radiolarite successions. This suggests the Middle Jurassic onset of ophiolite obduction which triggered the drag down of the Adria margin documented by the abrupt change from carbonate to radiolarite deposition.

\section{ACKNOWLEDGEMENT}

This research was supported by the Ministry of Education Science and Technological Development of the Republic of Serbia, Project No. 176015 and by the Russian Governmental Program no 0135-2018-0033. The authors greatly appreciate the valuable comments given by Hans-Jürgen GAWLICK, Renata JACH and an anonymous reviewer and the help of John ROGERS who improved the English language of the manuscript. Lastly, we would like to pay our gratitude and our respects to our friend and colleague, Nataša GERZINA. After many joint fieldtrips, Nataša GERZINA passed away in June 2019. The study would not have been possible without the extraordinary knowledge and collaboration of the esteemed Nataša GERZINA.

\section{REFERENCES}

AUBOUIN, J., BONNEAU, M., CELET, P., CHARVET, J., CLEMENT, B., DEGARDIN, J.M., DERCOURT, J., FERRIÈRE, J., FLEURY, J.J., GUERNET, C., MAILLOT, H., MANIA, J.H., MANSY, J.L., TERRY, J., THIEBAULT, P., TSOFLIAS, P. \& VERRIEUZ, J.J. (1970): Contribution à la géologie des Hellénides: le Gavrovo, le Pinde et la zone ophiolitique subpélagonienne.-Ann. Soc. Géol. Nord, 90, 277-306.

BAUMGARTNER, P.O., O’DOGHERTY, L., GORIČAN, Š., DUMITRICA-JUD, R., DUMITRICA, P., PILlEVUIT, A., URQUHART, E., MATSUOKA, A., DANELIAN, T., BARTOLINI, A., CARTER, E.S., DE WEVER, P., KITO, N., MARCUCCI, M. \& STEIGER, T.A. (1995a) Radiolarian catalogue and systematics of Middle Jurassic to Early Cretaceous Tethyan genera and species.- In: BAUMGARTNER, P.O., O'DOGHERTY, L., GORIČAN, Š., URQUHART, E., PILLEVUIT, A. \& DE WEVER, P. (eds.): Middle Jurassic to Lower Cretaceous radiolaria of Tethys: Occurrences, Systematics, Biochronology. Mémories de Géologie, 23, 37-685.

BAUMGARTNER, P.O., BARTOLINI, A., CARTER, E.S., CONTI, M., CORTESE, G., DANELIAN, T., DE WEVER, P., DUMITRICA, P., DUMITRICA-JUD, R., GORIČAN, Š., GUEX, J., HULL, D., KITO, N., MARCUCCI, M., MATSUOKA, A., MURCHEY, B., O'DOGHERTY, L., SAVARY, J., VISHNEVSKAYA, V., WIDZ, D. \& YAO, A. (1995b): Middle Jurassic to Early Cretaceous radiolarian biochronology of Tethys based on Unitary Associations.- In: BAUMGARTNER, 
P.O., O'DOGHERTY, L., GORIČAN, Š., URQUHART, E., PILLEVUIT, A. \& DE WEVER, P. (eds.): Middle Jurassic to lower Cretaceous radiolaria of Tethys: Occurrences, Systematics, Biochronology.- Mémories de Géologie, 23, 1013-1048.

BRAGIN, N.Y., BRAGINA, L.G., DJERIĆ, N. \& TOLJIĆ, M. (2011): Triassic and Jurassic radiolarians from sedimentary blocks of ophiolite mélange in the Avala Gora area (Belgrade surroundings, Serbia).--Stratigraphy and Geological Correlation, 19/6, 631-640. doi: 10.1134/S0869593811050030

BRAGIN, N.Y., BRAGINA, L.G., DJERIĆ, N. \& GERZINA SPAJIĆ, N. (2019a): Late Triassic radiolarians from the Grivska Formation.- Geološki anali Balkanskoga poluostrva, 80/1, 17-27.

BRAGIN, N.Y., BRAGINA, L.G., GERZINA SPAJIĆ, N., DJERIĆ, N. \& SCHMID, S. (2019b): New radiolarian data from the Jurassic ophiolitic mélange of Avala Mountain (Serbia, Belgrade Region).- Swiss Journal of Geosciences, 112/1, 235-249. doi: 10.1007/s00015-018-0313-8

CHIARI, M., BAUMGARTNER, P., BERNOULLI, D., BORTOLOTTI, V., MARCUCCI, M., PHOTIADES, A. \& PRINCIPI, G. (2013): Late Triassic, Early and Middle Jurassic Radiolaria from ferromanganese-chert "nodules" (Angelokastron, Argolis, Greece): evidence for prolonged radiolarite sedimentation in the Maliac-Vardar Ocean.- Facies, 59, 391-424. doi: 10.1007/s10347-012-0314-4

CHIARI, M., DJERIĆ, N., GARFAGNOLI, F., HRVATOVIĆ, H., KRSTIĆ, M., LEVI, N., MALASOMA, A., MARRONI, M., MENNA, F., NIRTA, G., PANDOLFI, L., PRINCIPI, G., SACCANI, E., STOJADINOVIĆ, U. \& TRIVIĆ, B. (2011): The Geology of the Zlatibor-Maljen area (Western Serbia): A Geotraverse across the Ophiolites of the Dinaric-Hellenic collisional belt.- Ofioliti, 36/2, 139-166.

DIMITRIJEVIĆ, M.D. (1974): The Dinarides: A model based on "now Global Tectonics".- In: Metallogeny and Concepts of the Geotectonic Development of Yugoslavia, Symposium, RGF, 141-178, Beograd.

DIMITRIJEVIĆ, M.D. (1997): Geology of Yugoslavia.- Geological Institute GEMINI, Belgrade, $187 \mathrm{p}$.

DIMITRIJEVIĆ, M.N. \& DIMITRIJEVIĆ, M.D. (1991): Triassic carbonate platform of the Drina-Ivanjica element (Dinarides).- Acta Geol. Hung., 34, 15-44.

DJERIĆ, N., GERZINA, N. \& SCHMID, M.S. (2007): Age of the Jurassic radiolarian chert formation from the Zlatar Mountain (SW Serbia).- Ofioliti, 32/2, 101-108.

DJERIĆ, N., GERZINA, N. \& SCHMID, M.S. (2012): Middle Jurassic radiolarian assemblages from the sedimentary cover of the Adriatic margin (Zlatibor Mountain, SW Serbia).- Bulletin de la Société Géologique de France, 183/4, 359-368.

FERRIÈRE, J., CHANIER, F., BAUMGARTNER, P.O., DUMITRICA, P., CARIDROIT, M., BOUT-ROUMAZEILLES, V., GRAVELEAU, F., DANELIAN, T. \& VENTALON, S. (2015): The evolution of the Triassic-Jurassic Maliac oceanic lithosphere: insidhts from the supra-ophiolitic series of Othris (continental Greece).Bulletin de la Société Géologique de France, 186/6, 399-411. doi: 10.2113/ gssgfbull.186.6.399

GAWLICK, H.-J., MISSONI, S., SUDAR, M.N., SUZUKI, H., MĖRES, S., LEIN, R. \& JOVANOVIĆ, D. (2018): The Jurassic Hallstatt Mèlange of the Inner Dinarides (SW Serbia): Implications for Triassic-Jurassic geodynamic and palaeogeographic reconstructions of the Western Tethyan realm.- Neues Jahrbuch für Geologie und Paläontologie Abhandlungen, 288/1, 1-47.

GAWLICK, H.-J., SUDAR, M.N., MISSONI, S., SUZUKI, H., LEIN, R. \& JOVANOVIĆ, D. (2017): Jurassic geodynamic history of the Dinaridic Ophiolote Belt (Innere Dinarides, SW Serbia).- Journal of Alpine Geology, 55, 1-167.

GAWLICK, H.-J., SUDAR, M., SUZUKI, H., DJERIĆ, N., MISSONI, S., LEIN, R. \& JOVANOVIĆ, D. (2009): Upper Triassic and Middle Jurassic radiolarians from the ophiolitic melange of the Dinaridic Ophiolite Belt, SW Serbia.- Neues Jahrbuch für Geologie und Paläontologie, 253/2-3, 293-311. doi: 10.1127/00777749/2009/0253-0293

GAWLICK, H.-J., MISSONI, S., SUZUKI, H., SUDAR, M., LEIN, R. \& JOVANOVIĆ, D. (2016): Triassic radiolarite and carbonate components from the Jurassic ophiolitic mélange (Dinaridic Ophiolite Belt).- Swiss Journal of Geosciences, 109/3, 473-494. doi: 10.1007/s00015-016-0232-5
GAWLICK, H.-J. \& MISSONI, S. (2019): Middle-Late Jurassic sedimentary mélange formation related to ophiolite obduction in the Alpine-Carpathian-Dinaridic Mountain Range.- Gondwana Research, 74, 144-172. doi: 10.1016/j.gr.2019.03.003

GORIČAN, Š., KARAMATA, S. \& BATOĆANIN-SREĆKOVIĆ, D. (1999): Upper Triassic (Carnian-Norian) Radiolarians in cherts of Sjenica (SW Serbia) and the time span of the oceanic realm ancestor of the Dinaridic Ophiolite Belt.- Bulletin Classe des Sciences Mathèmatiques et Naturelles Sciences Naturelles Academie Serbe des Sciences et des Arts, 39, 141-149.

GRILL, J. \& KOZUR, H. (1986): First evidence on the Unuma echinatus radiolarian Zone in the Rudabánya Mts (Northern Hungary).- Geol. Paläont. Mitt. Innsbruck, 13/11, 239-275.

KARAMATA, S. (2006): The geological development of the Balkan Peninsula related to the approach, collision and compression of Gondwanan and Eurasian units.- In: ROBERTSON, A. H.F. \& MOUNTRAKIS, D. (eds.): Tectonic development of the eastern mediterranean region. The Geological Society, London, special publications, 155-178. doi: 10.1144/GSL.SP.2006.260.01.07

MISSONI, S., GAWLICK, H.-J., SUDAR, M.N., JOVANOVIĆ, D. \& LEIN, R. (2012): Onset and demise of the Wetterstein Carbonate Platform in the mélange areas of the Zlatibor mountain (Sirogojno, SW Serbia).-Facies, 58, 95-111. doi: 10.1007/ s10347-011-0274-0

O'DOGHERTY, L., BILL, M., GORIČAN, Š., DUMITRICA, P. \& MASSON, H. (2006): Bathonian radiolarians from an ophiolitic mélange of the Alpine Tethys (Gets Nappe, Swiss-French Alps).-Micropaleontology, 51, 425-485. doi: 10.2113/ gsmicropal.51.6.425

O'DOGHERTY, L., GORIČAN, Š. \& GAWLICK, H.-J. (2017): Middle and Late Jurassic radiolarians from the Neotethys suture in the Eastern Alps.- Journal of Paleontology, 91/1, 25-72. doi: 10.1017/jpa.2016.96

OBRADOVIĆ, J. \& GORIČAN, Š. (1988): Siliceous Deposits in Yugoslavia: Occurrences, Types, and Ages.- In: HEIN, J.R. \& OBRADOVIĆ, J. (eds.): Siliceous Deposits of the Tethys and Pacific Regions. Springer, 51-64. doi: 10.1007/978-14612-3494-4_4

PANTIĆ, S. \& RAMPHOUX, J.-P. (1972): Concerning the Triassic in the Yugoslavian inner Dinarids (Southern Serbia, eastern Montenegro): microfacies, microfaunas, an attempt to give a paleogeographic reconstitution.- Mitt. Ges. Geol. Bergbaust., 21, 311-326.

RADOIČIĆ, R., JOVANOVIĆ, D. \& SUDAR, M. (2009): Stratigraphy of the Krš Gradac section (SW Serbia).- Geološki anali Balkanskoga poluostrva, 70, 23-41. doi: 10.2298/GABP0970023R

RAMPNOUX, J.-P. (1970): Regards sur les Dinarides internes yougoslaves (SerbieMonténégro oriental): stratigraphie, évolution paléogéographique, magmatisme.Bull. Soc. Géol. Fr., 7, 12, 6, 948-966. doi: 10.2113/gssgfbull.S7-XII.6.948

SCHMID, S., BERNOULLI, D., FÜGENSCHUH, B., MATENCO, L., SCHEFER, S., SCHUSTER, R., TISCHLER, M. \& USTASZEWSKI, K. (2008): The AlpineCarpathian-Dinaridic orogenic system: correlation and evolution of tectonic units.Swiss Journal of Geosciences, 101, 139-183. doi: 10.1007/s00015-008-1247-3

SUDAR, M. \& GAWLICK, H.-J. (2018): Emendation of the Grivska Formation in their type area (Dinaridic Ophiolite Belt, SW Serbia).- Geološki anali Balkanskoga poluostrva, 79/1, 1-19. doi: 10.2298/GABP1879001S

SUDAR, M., GAWLICK, H.-J., LEIN, R., MISSONI, S., KOVÁCS, S. \& JOVANOVIĆ, D. (2013): Depositional environment, age and facies of the Middle Triassic Bulog and Rid formations in the Inner Dinarides (Zlatibor Mountain, SW Serbia): evidence for the Anisian break-up of the Neotethys Ocean.- Neues Jahrb. Geol. Paläontol. Abh., 269, 291-320. doi: 10.1127/0077-7749/2013/0352

SUZUKI, H. \& GAWLICK, H.-J. (2009): Jurassic radiolarians from cherty limestones below the Hallstatt salt mine (Northern Calcareous Alps, Austria).- Neues Jahrb. Geol. Paläontol. Abh., 251, 155-197. doi: 10.1127/0077-7749/2009/0251-0155

VISHNEVSKAYA, V., DJERIĆ, N. \& ZAKARIADZE, G.S. (2009): New data on Mesozoic Radiolaria of Serbia and Bosnia, and implications for the age and evolution of oceanic volcanic rocks in the Central and Northern Balkans.- Lithos, 108/1-4, 72-105. doi: 10.1016/j.lithos.2008.10.015 


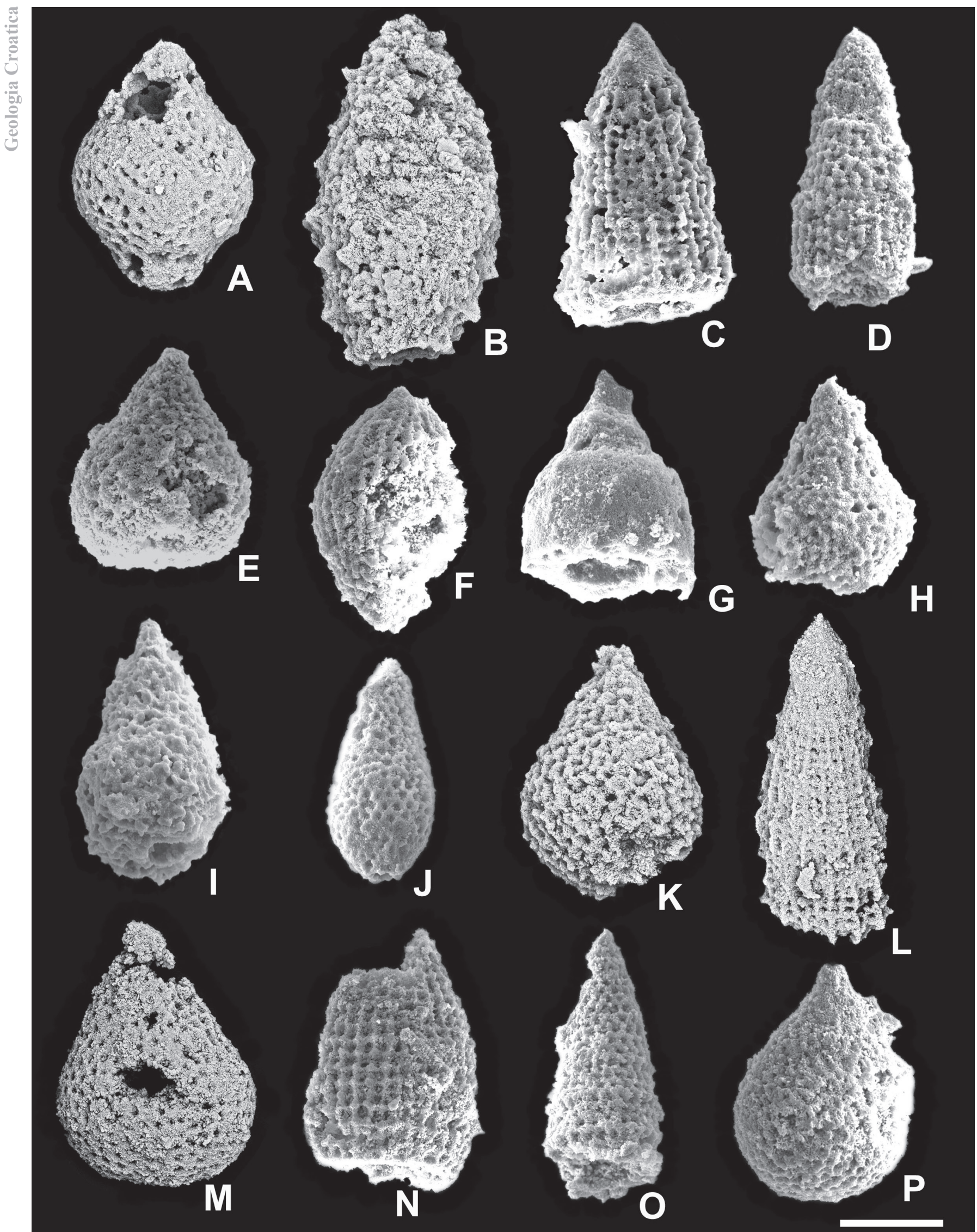

Plate 1. Middle Jurassic (Bajocian to Bathonian) radiolarians from the Djokov Potok section (Samples 15-10-7, 15-10-8 and 15-10-10). A - Japonocapsa fusiformis (YAO); B - Eoxitus hungaricus KOZUR; C - Parahsuum sp.; D - Parahsuum sp.; E - Quarkus japonicus (YAO); F - Helvetocapsa matsuokai (SASHIDA); G - Eucyrtidiellum sp. cf. E. unumaense s.I. (YAO); H - Quarticella sp.; I - Parvimitrella sp.; J - Campanomitra? sp. A sensu O'DOGHERTY, GORIČAN \& GAWLICK, 2017; K - Praewilliriedellum sp.; L - Hsuum sp. cf. H. matsuokai ISOZAKI \& MATSUDA; M - Praewilliriedellum convexum (YAO); N - Parahsuum sp. cf. P. izeense (PESSAGNO \& WHALEN); O Takemuraella veghae (GRILL \& KOZUR); P - Praewilliriedellum convexum (YAO). Figs. A-C, E-I - sample 15-10-7; Figs. J, K - sample 15-10-8; Figs. D, L-P - sample 15-10-10. Scale bar - $80 \mu \mathrm{m}$ for figs. C, N and P; $50 \mu \mathrm{m}$ for figs. A, B, D-M, $\mathbf{O}$. 


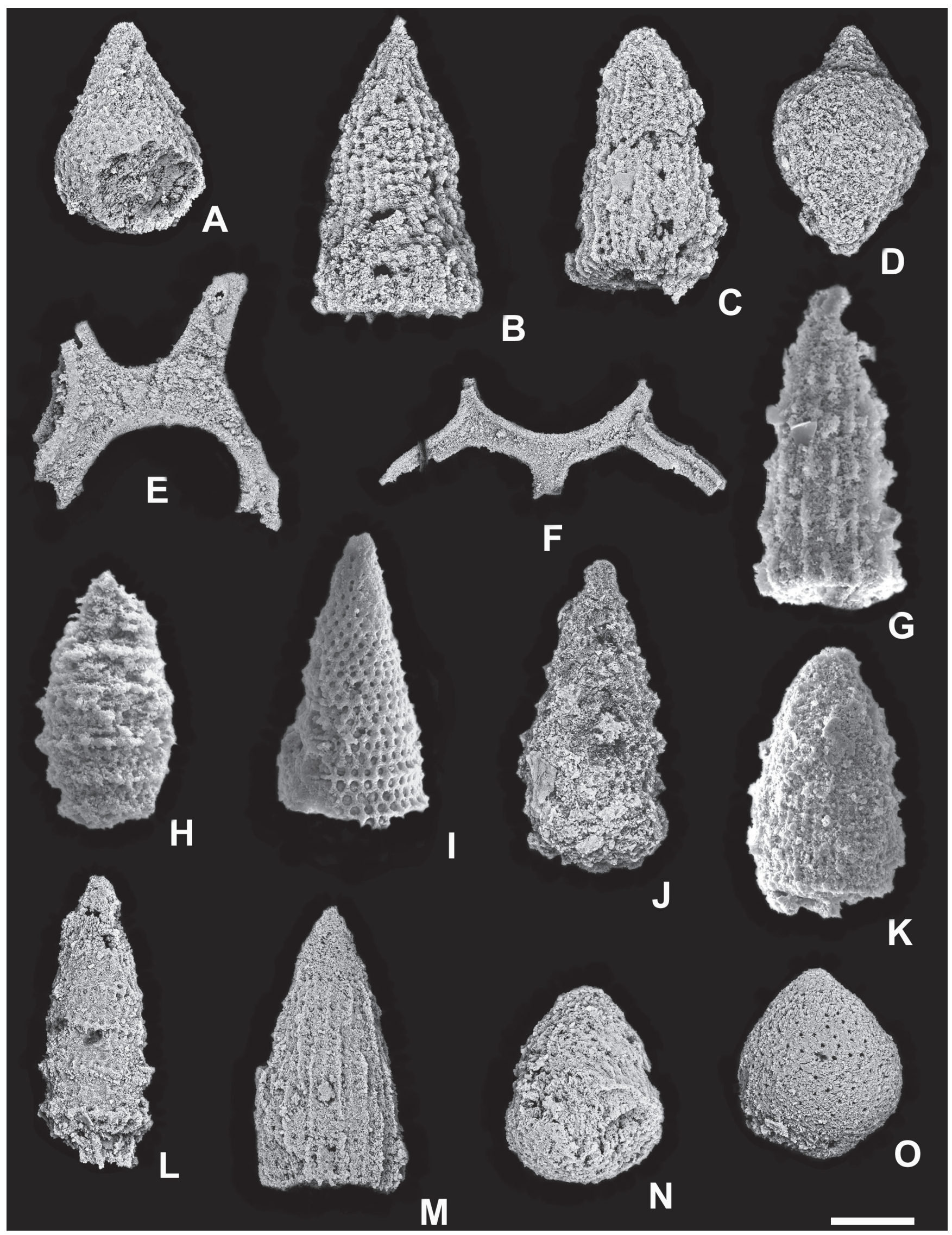

Plate 2. Middle Jurassic (Bajocian to Bathonian) radiolarians from the Djokov Potok section (samples 15-10-10 and 15-10-11). A - Praewilliriedellum convexum (YAO); B - Parahsuum sp.; C - Hsuum sp. cf. H. baloghi GRILL \& KOZUR; D - Quarticella sp. D sensu O'DOGHERTY, GORIČAN \& GAWLICK, 2017: E - Hexasaturnalis suboblongus (YAO); F - Hexasaturnalis tetraspinus (YAO); G - Transhsuum sp.; H - Eoxitus baloghi KOZUR; I - Takemuraella veghae (GRILL \& KOZUR); J - Pseudoristola sp. cf. P. durisaeptum (AITA); K - Parahsuum sp. cf. P. indomitum (PESSAGNO \& WHALEN); L - Mizukidella sp.; M - Hsuum sp.; N - Theocapsomella sp.; $\mathbf{O}$ - Japonocapsa fusiformis (YAO). Figs. A-F - sample 15-10-10: figs. G-O - sample 15-10-11. Scale bar - F - $100 \mu \mathrm{m}$, other figures - $50 \mu \mathrm{m}$. 